\title{
Challenges Faced by Newly Inducted Teachers Implementing Revised English Curriculum in Pakistan
}

\author{
Atta Ur Rehman Jadoon ${ }^{1}$, Muhammad Ilyas Chishti ${ }^{2}$, Muhammad Afzaal ${ }^{3,4}$ \& Tahir Afzal ${ }^{1}$ \\ ${ }^{1}$ Department of English, Foundation University Islamabad \\ ${ }^{2}$ School of Natural Sciences, National University of Sciences and Technology, Islamabad \\ ${ }^{3}$ Department of English, Foundation University Islamabad, Pakistan \\ ${ }^{4}$ Shanghai International Studies University, China \\ Correspondence: Muhammad Afzaal, Senior Lecturer, Department of English, Foundation University Islamabad. \\ E-mail: Muhammad.afzaal1185@gmail.com
}

Received: May 15, 2020

doi: 10.5539/elt.v13n7p52
Accepted: June 11, 2020

Online Published: June 12, 2020

URL: https://doi.org/10.5539/elt.v13n7p52

\begin{abstract}
In the modern world of today, English language is frequently used as a medium of communication at the international level and among the multilingual speakers. The grand significance of the English language in the global village stresses all the stakeholders and policymakers in Pakistan to initiate and execute appropriate teaching methods for successful learning of English language. In view of the demands of the modern world, the provincial government of Khyber Pakhtunkhwa (KPK), Pakistan implemented the revised English curriculum and inducted new teachers with better qualification to ensure its desired outcomes. Revised English curriculum, handed over to the newly inducted teachers to implement was supposed to pose a variety of challenges. The current study investigated those challenges faced by these newly inducted teachers implementing revised English curriculum. The study was limited to the newly inducted teachers teaching English at secondary level in district Abbottabad (KPK), Pakistan. Employing a mixed-method research based on purposeful sampling, the data was initially collected through semi structured interviews of the focussed group of the research participants and further validated by means of survey questionnaire filled by the entire research population. The findings of the study revealed that inappropriate classrooms with deficient resources posed major challenges for the teachers to effectively communicate the revised curriculum. Moreover, lack of students' involvement in the lessons and teachers' insufficient awareness to curriculum impeded the curriculum implementation as desired. The current study stressed on the remedial measures to be taken on part of the government officials and the school administration to ensure the availability of resources required for English language learning and encouragement of learners' involvement in the lessons. Moreover, teachers should be provided with appropriate training to meticulously implement the revised English curriculum.
\end{abstract}

Keywords: secondary level, newly inducted teachers, teachers' challenges, ESL curriculum implementation

\section{Introduction}

In the present world, English language is a common medium of communication at international level and among the speakers of different languages. There are more than two billion people who communicate in English language with different accents and have different levels of proficiency (Crystal, 1997). Since after having crossed the geographical boundaries of Great Britain the number of English language speakers has risen to a great extent, it has proved to be a dominant language employed in the global settings. English language has been used for communication in research, publication, business, and commerce and has helped discover uncountable prospects in various fields of life.

In Pakistan, the official communication and correspondence is made in English in majority of the Government settings. A cluster of professional fields, such as medicine, engineering, business administration, education and information technology are operating English as a medium of communication. Employers other than ensuring the desired qualification among employees, prefer them coming up with excellent command in written and spoken English. English as a compulsory subject in education is of supreme value in preparing the learners to take up the challenges of the competitive survival and growing globalization in developing countries. The grand significance 
of English in Pakistan demands from all the stakeholders and policy makers to initiate and execute appropriate teaching methods for successful learning of English as a second language.

In Pakistan, it has been commonly observed that students having excellent competencies in English language definitely get entry into institutions of the best repute while students having poor background in English language are deprived of such entry. At secondary level, the importance of English language is even more intense as this developmental level prepares learners either to make a successful entry to the higher institutions with a sound academic record or to be a valuable member for the family by joining various prestigious trades.

In 2012, the revised English curriculum was implemented in Khyber Pakhtunkhwa, one of the provinces of Pakistan. Teacher's prior experience of teaching English and their existing beliefs were utterly ignored. In addition to this, they were not provided with any kind of help to understand it and accept its features so as to implement it as desired by the curriculum designers. These teachers have not been provided with sufficient training to cope with the revisions in the curriculum and thus shifting from the outdated practices to the innovative and modernized techniques has been quite impossible. Therefore, due to lack of appropriate training, teachers were left with only one option to rely on their previous experience in the implementation of revised English curriculum and it resulted in the application of obsolete methodology in its implementation. It has created a wide gap between the written curriculum and the operational curriculum. Thus, the teacher failed to implement revised English curriculum in its true letter and spirit.

According to Richards (2013), curriculum is a comprehensive plan for a course which highlights how course contents are converted into a master plan for teaching and learning in order to facilitate successful completion of desired learning outcomes. He further mentions that the development of the curriculum for English language teaching starts from a selection of the linguistic content based on the needs of the learners. Classroom activities and learning materials are developed on the basis of the selected linguistic content. These activities and learning material affect the classroom teaching techniques and procedures leading towards student learning outcomes.

The curriculum has been split into three dimensions by Purkey and Smith (1983, cited in Razali, 2007). The first dimension is the intended curriculum which is the official document designed by the curriculum developers. The second dimension is the implemented curriculum which is the practical form of the curriculum presented to the students through classroom teaching. The third dimension is the attained curriculum. This is what the students have attained at the end of the instruction.

In the context of the current research, the revised English Curriculum has also been split into three dimensions: The written curriculum that refers to the official document of the national curriculum for English language teaching published in 2006. It provides a brief outline of the knowledge and skills that teachers have to teach. The second dimension is the taught curriculum which is the knowledge and skills desired to be inculcated among students during the course of instruction. Textbooks are usually referred to as taught curriculum. The third dimension is the examined curriculum which refers to evaluate what the students have acquired at the end of the instruction.

The dimensions of the revised English curriculum stated above are in complete disagreement with insights of Purkey and Smith mentioned above. They interpreted the curriculum exclusively with reference to all the stakeholders involved in it whereas the revised English curriculum is a blend of stakeholders and educational affairs.

According to Government of Pakistan (2006), a curriculum refers to three elements (i.e., the knowledge, a set of language skills and competencies) that formulate the content of the subject to be taught. Moreover, the curriculum is designed to accomplish the desired objectives through teaching and learning and thus fruitfully contributes to providing a competitive edge to the students at an international level.

Based on this perspective, the revised English curriculum does not solely involve attainment of knowledge but also stresses on the enhancement of linguistic competence to ensure complete growth of the learners. So, the curriculum mainly targets the enhancement of communicative competence of the learners and focuses on teaching language instead of teaching about the language. Thus, the taught curriculum and the examined curriculum are bound to be in line with the intent of the written curriculum.

The teacher has got to play unique roles in society and has become the focus of attention in the modern world. Being builders of the nation, majority of the members of the society pass through the moulding hands of teachers. Teachers are the curriculum implementation agents. The curricular reforms and revisions require teachers to incorporate big changes in their teaching practices for better implementation (Penuel, Fishman, Yamaguchi \& Gallagher, 2007). Teachers are the key players in the curriculum who can produce the desired outcome of revision and reforms (Wu, 2001). In the context of the current research, the importance of teachers cannot be denied as they 
have to play the most important part in the curriculum implementation as even the best plan can be of no use if it is not implemented well and thus without the eagerness, support and cooperation of the teachers, effective curriculum implementation is beyond the bounds of possibility. Therefore, revision of the curriculum will be worthless if it does not engage the teachers as the implementing agents to enhance students' outcomes (Cuban 1998; Afzaal,2019, cited in Priestly, 2005). Afzaal et.al. (2019) also argues on the the classroom interaction between the teachers and the pupils and transcribed the conversation to interpret it. Thus, teachers are responsible to a great extent for the successful employment of curricular change and revision as they pass on the revisions through their classroom teaching (Rahman \& Haslynda, 2014).

Teachers and students are the major key players in the implementation of curriculum reforms and revisions. In the context of teaching English, the role of teacher is very important to ensure the productive implementation of the reforms and revisions made in the curriculum. However, in certain situations, teacher is considered responsible for the lack of success in the implementation of proposed revisions and reforms in the curriculum. The studies on the implementation of revised curriculum, however, argue that there are certain factors which impinge on successful implementation of curriculum reforms and revisions.

In Libyan context, Orafi (2008) and Orafi and Borg (2009) find that there has been limited implementation of new communicative English language curriculum due to disparity between the examination and the objectives of the curriculum and limited teacher training. Bantwini (2010) highlighted that social issues surrounding the teachers and school were neglected by curriculum designers and it resulted in the lack of success in the implementation of revised curriculum to produce the outcomes as desired.

In Turkey, Tılfarlığlu and Öztürk (2007) investigated the challenges faced by teachers in the effective execution of English language curricula and noted that teachers were unable to apply learner-centred approaches requiring active participation of students due to overly large classes. Bantwini (2010) also claims that it is exclusively devastating and infuriating for teachers to teach in overcrowded classroom, as teachers cannot fully concentrate on progress of all the learners. It indicates that students in overcrowded classes do not get the attention of the teacher and have very limited opportunities to actively participate in listening and speaking activities (Tabatabaei \& Pourakbari, 2012). Thus, over-crowding has obstructed adequate teaching and efficient learning.

O'Sullivan (2002) and Bantwini, (2010) emphasize that the objectives of curriculum cannot be achieved in the intended manner as the physical conditions of the classrooms were inadequate and teachers were bound to work within the prevailing context challenging them with poor infrastructure and lack of support services. Hence, successful implementation of revised curriculum stresses the need of suitable environment for effective teaching (Gömleksiz, 2005).

Another challenge that teachers have to cope with is the mismatch between the policy goals and examinations. The literature highlights that instead of focusing on the learning outcomes most of the education systems exclusively focus on examinations (Hassan \& Selamat, 2002; Pandian, 2002; Sidhu, Fook \& Kaur, 2010). Thus, instruction is custom-made to what is tested, and teachers tend to teach to the test (Wang, 2008; Kırkgoz, 2009). Curriculum implementation in the classroom mainly focuses on the techniques of answering various types of questions frequently asked in the examinations. In the case of language, instead of developing language skills as desired by the curriculum, only those aspects of language are taught which are usually tested and thus learners fail to learn the language and cram the questions to pass their examinations (Kausar \& Akhtar, 2013). It clearly suggests that all those issues need to be addressed on priority that obstruct to harmonize the written curriculum with the taught curriculum and the examined curriculum.

Moreover, in the context of English language curriculum implementation the role of teacher is very significant to attain desired objectives. Teachers' perceptions, attitudes and beliefs in curriculum implementation have been cited as the most significant factor in the curriculum implementation. Carless (1998) points out that teaching and learning experience of teachers, their training, interaction with colleagues and values and norms of the society in which they work are the major elements that contribute significantly in constructing the perceptions and attitudes of the teachers. He further explains that it is imperative to know how teachers perceive curricular reforms and revisions and what attitudes they hold towards it as their real classroom activities will be governed by their perceptions and attitudes (Carless, 1998). It means that classroom practices are likely to be influenced by teachers' perceptions and attitudes. In Greek secondary school Karavas-Doukas (1995) found that teachers' beliefs pertaining to the learning process are not compatible with the principles of curriculum implementation and thus resulted into very limited implementation of communicative language teaching in the classroom. The studies from China (Hui, 1997; Penner, 1995) and Egypt (Holliday, 1996) reported the similar findings.

Clarity of understanding the learning objectives on the part of teachers posed another challenge in the effective 
enforcement of revised curriculum policies. Bantwini (2010) noted that teachers lacked ample information about the curriculum and were unable to understand what the curriculum desires from them to practice in their classroom teaching causing obstruction in the positive change and effective implementation. Wang (2008) stresses that due to lack of proper guidance about language teaching methods and confused perceptions of the syllabus, teachers applied outdated methods and inappropriate techniques in which they felt themselves comfortable. While carrying out a study on early responses of the teachers to the reforms in curriculum in California, Cohen and Ball (1990) revealed that due to inadequate knowledge of the curriculum revision some of the teachers turned to arrange the revised curriculum within their current teaching practices and thus they applied outdated methods in teaching new materials. Hence difference between teaching practices and the objectives of the curriculum caused absence of desired revisions.

Among other challenges stated above, the absence of appropriate curriculum resources and materials may also hinder the effective implementation of revised curriculum. Carless (1997) reported that the inaugural trail of the Target-Oriented Curriculum in Hong Kong was proved unsuccessful due to lack of teaching resources. Teachers simply avoided implementing the new curriculum due to non-availability of sufficient teaching materials. Moreover, if the teaching materials fail to precisely exhibit the desired intentions of curriculum, their development and presentation can be counterproductive. Kirgkoz (2008) highlighted that non implementation of Turkish Communicative Oriented Curriculum was in fact due to the failure of the textbooks designed to promote listening and speaking. He found that the activities in the textbook were not worthwhile for the students due to lack of contextualization which is mandatory for the implementation of communicative methodology.

Teachers' training is mandatory for successful attainment of curriculum objectives especially when the prescribed methodology is completely opposed to the one in practice and teachers are required to unlearn the obsolete methods and learn the new skills and knowledge (Carless, 1997). In case of inexperienced and untrained teachers, teachers' training is imperative to enhance demanded competence and proficiency (Morris, 1985; Suzuki, 2011). Kırgköz (2008b) mentions that the training imparted to the teachers is most critical as incomplete and inadequate training may cause imperfect awareness of the revisions in the curriculum. Research on curriculum reforms and revisions affirms that the curriculum is mostly put into practice in the deficiency of sufficient or adequate guidance (Bantwini, 2010; O'Sullivan, 2002). In the context of Greece, Karavas-Doukas (1993) highlighted that the teachers' training instead of dealing with classroom reality focused on conceptual issues and thus it resulted in the unsuccessful implementation of innovation in Greek secondary classrooms. Hence, he stressed on the need of practical training. While stressing the importance of training for effective implementation of the curriculum, Hayes (2000) highlighted that training should enable teachers to make a right choice of resources to be used in the classroom and adapt the materials relevant to their teaching context.

In Pakistan, various studies have been done to investigate the challenges posed by the implementation of revised English curriculum at secondary level and highlighted that the paucity of trained and qualified teachers has been one of the major issues hindering the successful implementation. Teachers who have been tasked to implement the curriculum were not completely familiar with its aims and objectives and thus they applied obsolete methods and utilized traditional techniques. In terms of their own competence, these teachers were not proficient in English language skills. Hence, paucity of competent and qualified English teachers has invariably challenged successful curriculum implementation. Teachers being curriculum implementation agents have been highlighted as main area of concern and their qualification and training has emerged as a weak link creating a disparity between written and operational curriculum (Nawab 2012, and Bashiruddin \& Qayyum, 2014).

Warsi (2004) stresses on the need of overhauling English curriculum with specific leaning objectives and Adalat (2005) highlighted that majority of English teachers used Grammar-Translation method and had not attended English language course. Karim (2006) also has the similar findings. Moreover, Faizi (2010) pointed out that the outmoded teaching methods are main reasons of declining educational standards at secondary level. Apart from that, Teevno (2011) found that lack of proper training of teaching English, non-availability of proper facilities and incompatibility of the curriculum to the needs of the students were the reasons that hindered the teaching and learning process.

Behlol, \& Anwar (2011) revealed that the results of GCE O-level are better due to the availability of competent teachers who practiced Direct, Audio Lingual and activity-based methods. They also revealed that Grammar Translation and Lecture methods were frequently used by the teachers at SSC level system. Whereas Shahzada et al. (2012) found that teachers of English are not qualified and well trained and they do not teach English in a proper manner.

Ahmed et al. (2013) conducted a study to investigate the factors affecting the learning of English of the secondary 
school students in Khyber Pakhtunkhwa. The main findings of the study revealed that the teachers in Provincial government schools were not sufficiently qualified and had no adequate knowledge of teaching methodologies of teaching English. The classes were overcrowded, and schools lacked audio-visual aids for teaching of English. While finding out the existing methodologies and their application for teaching English in the private schools of Dir Upper, KPK, Bacha, \& Ilyas (2014.) highlighted that majority of the teachers used outdated methods for teaching English at secondary level.

Soomro et al. (2016) investigated contemporary pedagogical techniques used for teaching and learning English and indicated that teachers were attached with some outdated techniques and activities; secondly, they also faced problems applying new techniques while teaching in a large multilevel classroom; thirdly, teachers had willingness to adopt and employ innovative techniques in classrooms and lastly, the notion of ESL best practices was uncommon among them. Most of the teaching strategies do not create better learning environment, and learners do not interestingly participate due outdated activities.

These studies recommended the appointment of fresh and better qualified teachers for English language teaching at secondary level as old teachers were unable to unlearn the obsolete practices and failed to adjust themselves according to the demands of revised English curriculum.

In 2014, the provincial government-initiated induction of fresh teachers to implement revised English curriculum at secondary level. These well-qualified teachers were selected through tough selection criteria including tests conducted by National Testing Service. Thus, the revision of English curriculum has also opened the ways for new teachers with better qualification to replace old teachers.

Considering the importance of effective implementation of revised English curriculum with its impact on multiple needs of learners in future, it is needed to explore the actual scene of revised English curriculum operating at Khyber Pakhtunkhwa (KP), Pakistan after the induction of fresh teachers. Investigation in terms of the challenges faced by these newly inducted teachers has not been conducted so far. Therefore, the current study will offer insights for all the key players of the revised English curriculum ranging from curriculum developer to curriculum implementer and evaluator.

Revised English curriculum is a comprehensive document dealing with academic levels from the beginner level to the intermediate level. The task of English language teaching at different academic levels in the province is being undertaken by two categories of teachers: the old and the new. However, the current research is delimited to the newly inducted teachers selected through National Testing Service (NTS) tests and tasked to implement revised English curriculum at secondary level (IX-X) in district Abbottabad, KPK province of Pakistan. Thus, the current research aimed at the exploration of the challenges confronted by newly inducted English teachers in delivering revised English curriculum at secondary level in Abbottabad.

\section{Method}

The main focus of the current research was to probe into the implementation of the revised English curriculum by newly inducted teachers at secondary level in Khyber Pakhtunkhwa (KP) and highlight the challenges faced by these teachers. Within the pragmatic research paradigm, it was a mixed-method research based on a survey study conducted in district Abbottabad of Khyber Pakhtunkhwa. It was based on purposeful sampling conducted on all the teachers, the participants of the subject research, inducted through NTS tests since 2014 and tasked to teach English at secondary level.

The research instruments used for data collection in the current research were semi-structured interviews and survey questionnaire. At the initial stage of data collection, a focused group containing ten newly inducted teachers (five male and female each) was formed and semi-structured interviews of the group participants were conducted. Teachers were given maximum time to speak freely on the challenges they frequently faced in their day-to-day teaching practice. The analysis of interview data helped the researchers to distribute the challenges into five categories:
(a) Classroom
(b) Resources
(c) Students' involvement
(d) Teachers' awareness
(e) Assessment

After getting to know about the challenges, a survey questionnaire was formulated to get the feedback from the entire research population which is an appropriate way of gathering data from a large number of research 
participants (Mathers et al., 2007). The survey questionnaire was based on close-ended questions and the respondents were bound to answer from the pre-coded responses given. These questions dealt with challenges highlighted by the focus group participants and the research participants were required to respond in terms of agreement on Likert (1932) scale. Initially, the questionnaire was piloted in district Rawalpindi, Punjab, Pakistan and suitable alteration was made in order to ensure the instrument validity.

\section{Data Analysis and Discussion}

There were total 18 male and 22 female teachers inducted through NTS who were tasked to teach English at secondary level in different schools of district Abbottabad, KPK, Pakistan. The questionnaires were administered to all the research participants and the detail of the questionnaire response is presented in the table below:

Table 1. Questionnaire Response Detail

\begin{tabular}{cccc}
\hline Sampled & Total & Returned & Percentage \\
\hline Male Teachers & 18 & 14 & $77.77 \%$ \\
Female Teachers & 22 & 18 & $81.81 \%$ \\
Total Questionnaires & 40 & 32 & $80.00 \%$
\end{tabular}

Out of 18 male teachers, 14 teachers returned the questionnaire which is the $77.77 \%$ of total male participants. Out of 22 female teachers, 18 teachers returned the questionnaire which is $81.81 \%$ of total female participants. It indicates that out of total 40 participants, 32 returned the questionnaire and it is $80 \%$ of the total research participants. This response rate was excellent for statistical inference as it conforms to Mugenda and Mugenda's (2003) stipulation. English teachers implementing revised English curriculum were confronted with many challenges and these challenges were further divided into following categories:

\subsection{Classroom}

Classroom poses certain challenges in the effective curriculum implementation. Overly large classes create inappropriate learning atmosphere. There is an impossibility to conduct a lesson based on small groups in a traditional classroom organization. Due to large number of students there are chances of loss of classroom control during various activities. In certain cases, the revised English curriculum seems to be incompatible with learning atmosphere. The summary of the responses is presented in the following diagram:

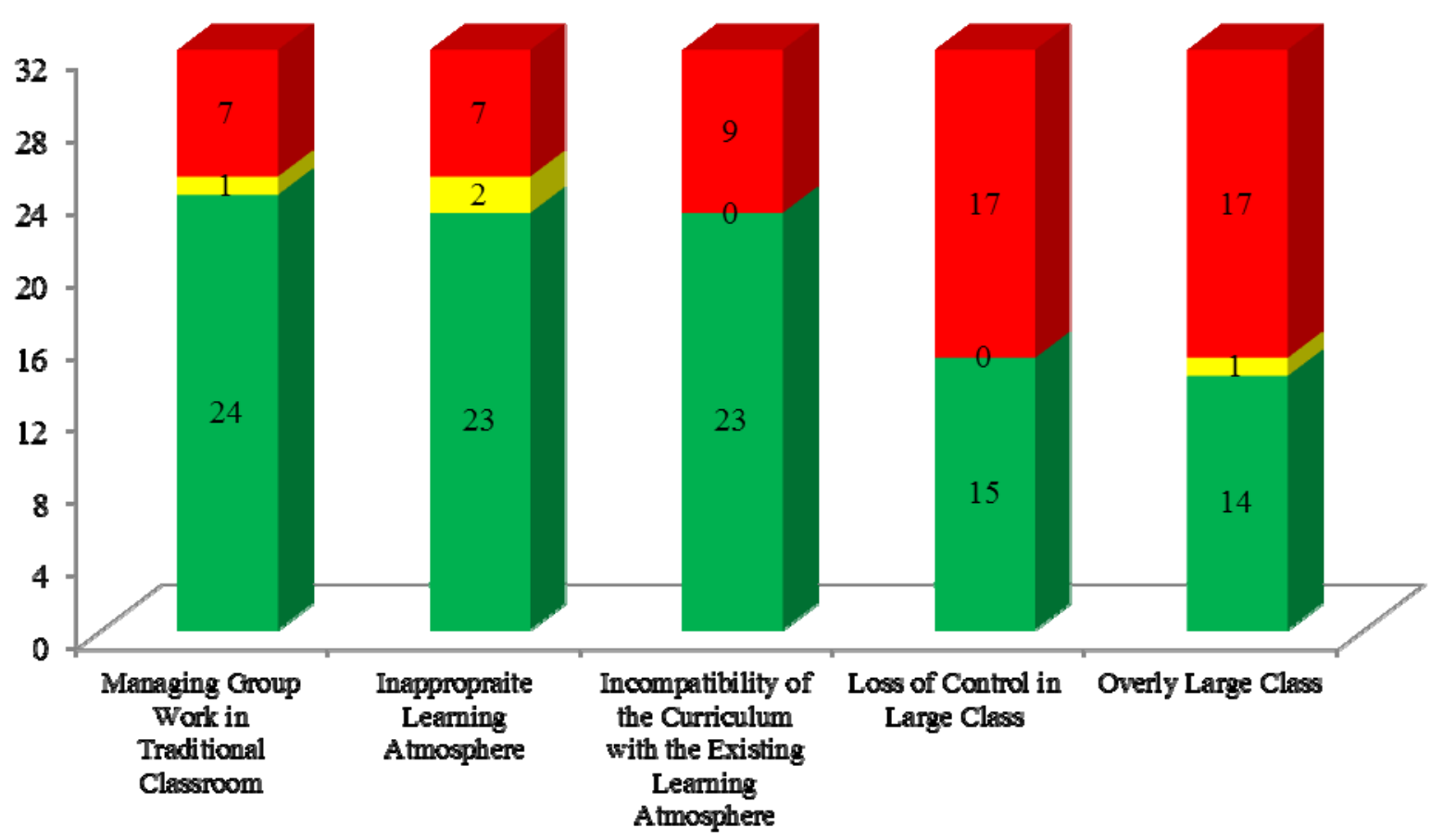

Agree $\quad$ Neutral $\quad$ Disagree

Figure 1. 
The detailed analysis of data highlights that 24 (75\%) teachers faced the challenge of managing group work in traditional classroom, $23(72 \%)$ have to deal with inappropriate classroom atmosphere, $23(72 \%)$ considered the curriculum incompatible with their existing learning atmosphere, 15 (47\%) have lost control in large class and $14(44 \%)$ have to encounter the challenge of overly large classes. It indicates that managing group work in the traditional classroom and inappropriate classroom atmosphere have been major challenges faced by newly inducted teachers in the category of classroom. Moreover, incompatibility of the curriculum with the existing learning atmosphere has also been noted as a matter of concern.

\subsection{Resources}

Resources play a vital role in the achievement of curriculum objectives and in case the resources are insufficient or inappropriate, there are chances of achieving lower results in curriculum implementation. Resources that pose the challenge in the curriculum implementation were inadequate materials, difficulty in using authentic materials, lack of libraries for lesson planning, need for teachers' guide and test books and need of language lab, equipped with audio visual aids for enhancement of students' listening comprehension and understanding. The summary of the responses is presented in the following diagram:

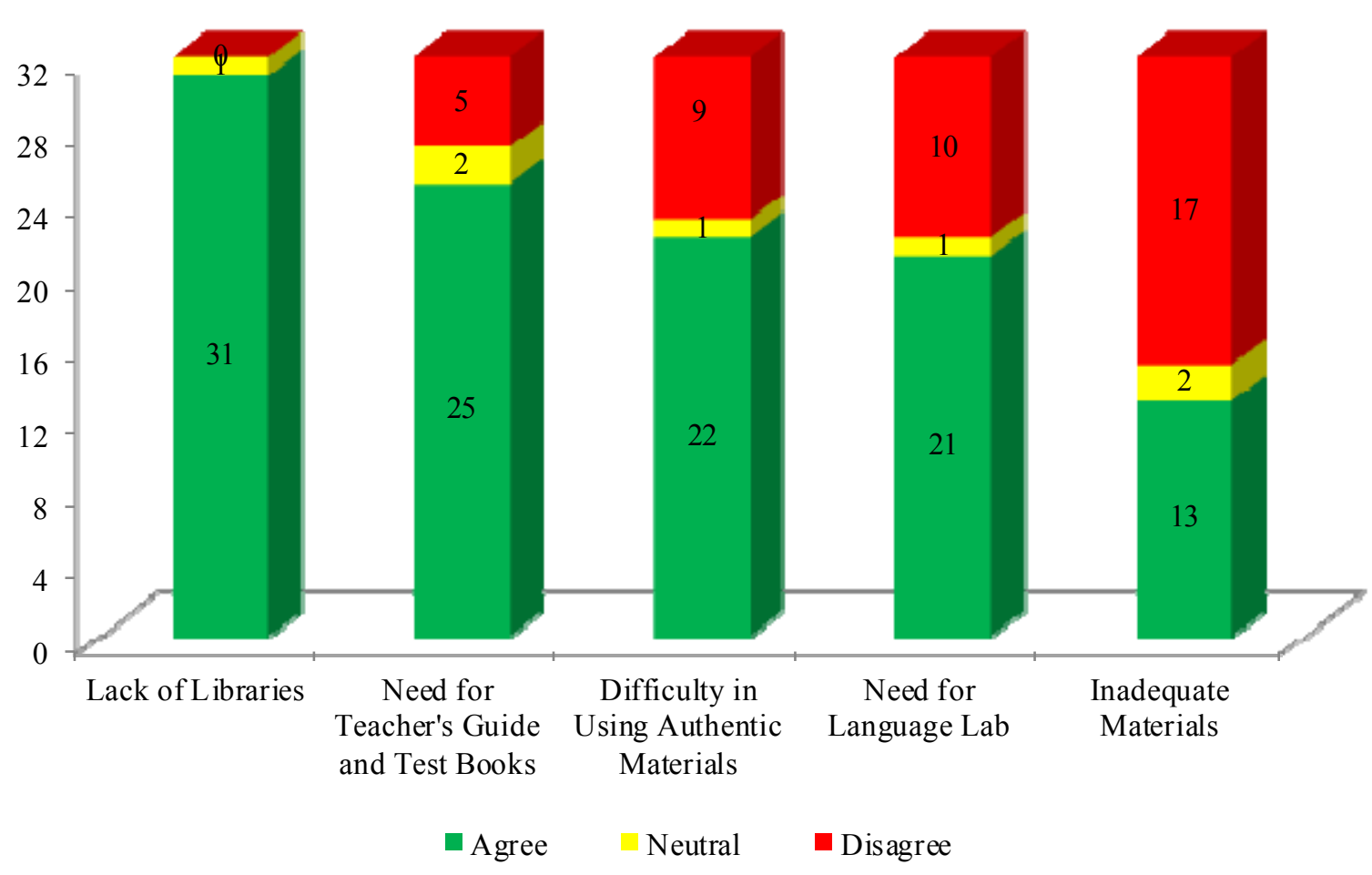

Figure 2.

The detailed analysis of data highlights that $31(97 \%)$ teachers confronted with the challenge of non-availability of suitable libraries, $25(78 \%)$ highlighted the need for teachers' guide and test book for lesson planning and assessment, 22 (69\%) were facing difficulty in using authentic materials in classroom, $21(65 \%)$ stressed on the need of language lab for enhancement of listening comprehension and motivating learners, and $13(41 \%)$ lacked adequate materials. It indicates that non-availability of suitable libraries has been major challenge faced by newly inducted teachers in the category of resources. Moreover, non-availability of teachers' guide and test book for lesson planning and assessment has also been highlighted as main obstacle hindering effective implementation of revised English curriculum.

\subsection{Students' Involvement}

Students' involvement poses a variety of challenges in the effective curriculum implementation including lack of motivation, use of native language, fear of mistakes, lack of interest in homework and disparate competencies. The summary of the responses is presented in the following diagram: 


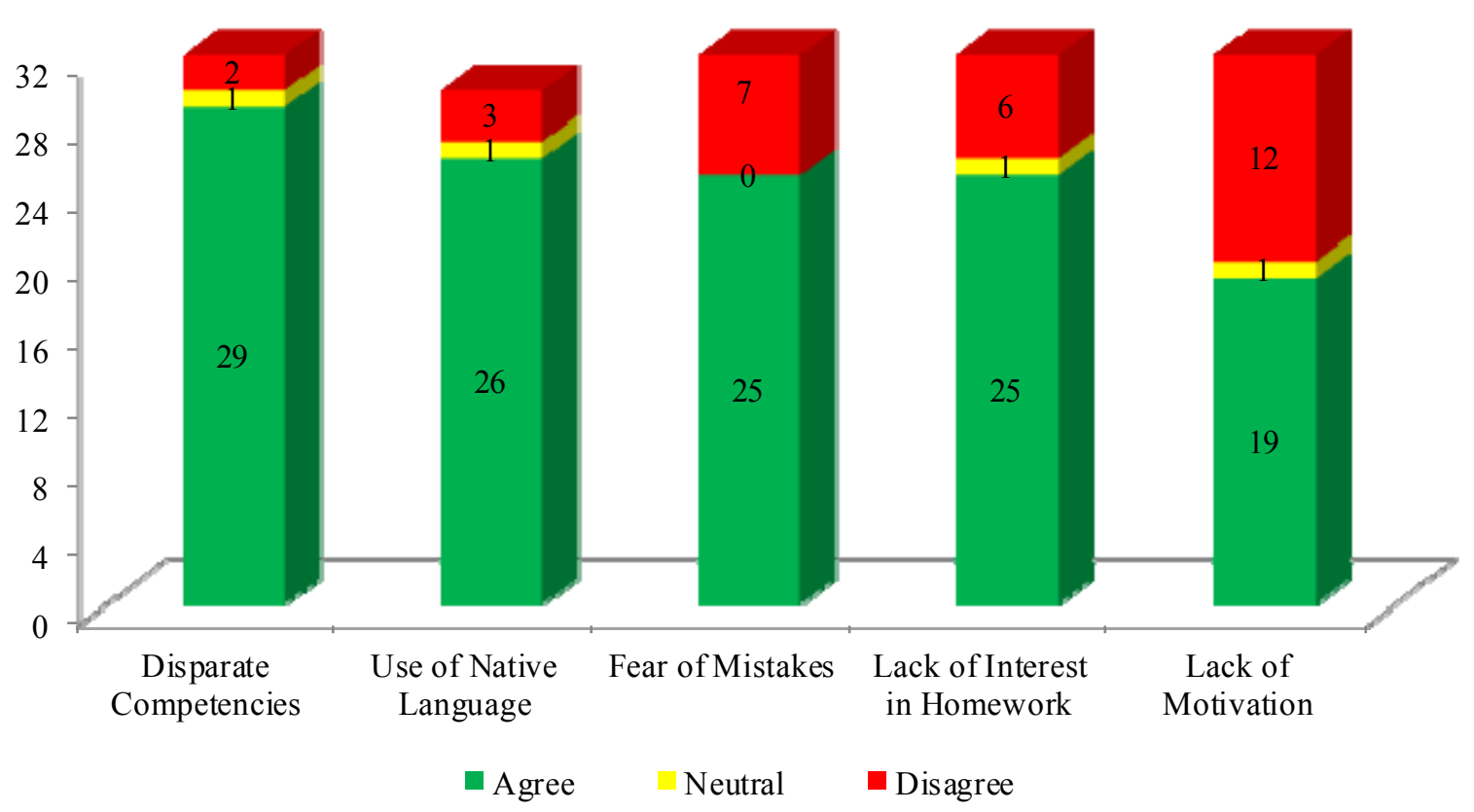

Figure 3.

The detailed analysis of data highlights that 29 (91\%) teachers confronted with the challenge of disparate competencies, it was impossible for $26(87 \%)$ teachers to ban the use of native language, $25(78 \%)$ highlighted students' lack of interest in homework, $25(78 \%)$ teachers noted fear of mistakes among the students while they try to speak English, and 19 (59\%) teachers underlined the lack of motivation among the students. It indicates that dealing with disparate competencies has been major challenge faced by newly inducted teachers pertaining to the challenges caused due to students' involvement. Moreover, impossibility to ban the use of native language and students' lack of interest in homework have also been highlighted as main obstacle hindering effective implementation of revised English curriculum. Apart from that, in order to help the students, speak English there has been main concern to remove their fear of mistakes.

\subsection{Teacher's Awareness}

The teacher lacked the awareness of aims and objectives of the revised curriculum. Due to their professional qualification, teachers preferred to use traditional methodology. Some of the teachers were incompetent to implement the revised English curriculum, and thus stressed on the need of training for the effective implementation. The summary of the responses is presented in the following diagram: 


\begin{tabular}{|c|c|c|c|c|c|}
\hline $2-$ & 0 & 4 & 9 & & \\
\hline $28-$ & & 3 & & & \\
\hline $24-$ & & & 2 & 23 & 21 \\
\hline $\begin{array}{l}0- \\
6-\end{array}$ & 32 & & & & \\
\hline & & 25 & 21 & & \\
\hline $8-$ & & & & 2 & 7 \\
\hline $4-$ & & & & 7 & 4 \\
\hline 0 ᄀ & & & & & , \\
\hline & $\begin{array}{l}\text { Need for } \\
\text { Training }\end{array}$ & $\begin{array}{c}\text { Use of } \\
\text { Traditional } \\
\text { Methodology }\end{array}$ & $\begin{array}{l}\text { Usefulness of } \\
\text { Professional } \\
\text { Qualification }\end{array}$ & $\begin{array}{c}\text { Incompetence } \\
\text { of Teacher }\end{array}$ & $\begin{array}{c}\text { Lack of } \\
\text { Curriculum's } \\
\text { Awareness }\end{array}$ \\
\hline & & Agree & Neutral & Disagree & \\
\hline
\end{tabular}

Figure 4.

The detailed analysis of data points out that all (32) the teachers $(100 \%)$ were in dire need of training for effective implementation of revised English curriculum and due to lack of training 25 most of (78\%) the teachers used traditional methodology as they were unable to teach English through communicative language teaching method. As many as $21(66 \%)$ teachers considered that their professional qualification is not enough for the successful implementation of the revised English curriculum. There were some (7) teachers (22\%) who considered that their English language teaching skills are not good enough to teach revised English curriculum. Very few (4) teachers (13\%) highlighted that they lacked awareness of the objectives of revised English curriculum. It indicates that majority of the teachers were bound to use the traditional methodology as their professional qualification did not help them to deal with revised curriculum and there were some few teachers who lacked awareness of revised English curriculum. Thus, all the teachers needed effective training to ensure the desired implementation of the curriculum.

\subsection{Assessment}

Assessing students performing a variety of activities and getting proper feedback is not possible due to time constraints. Moreover, final assessment taken by board of intermediate and secondary education is not compatible with communicative language teaching goals. However, achieving examination results is more important and valued by school than achieving communicative language teaching goals. The summary of the responses is presented in the following diagram: 


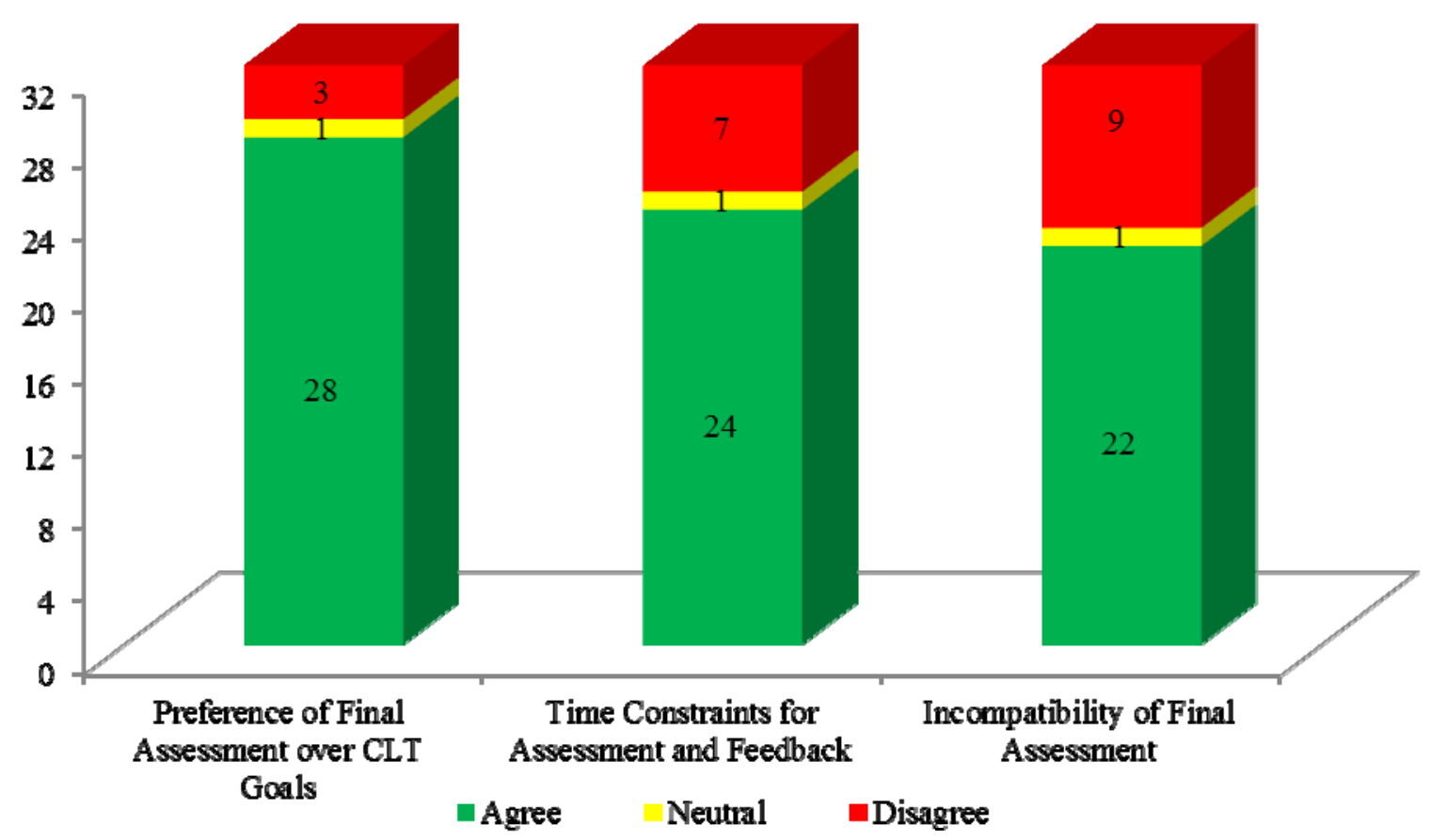

Figure 5.

The detailed analysis of data highlights that most $(28)$ of the $(88 \%)$ teachers have been stressed by the administration to prefer the final assessment over CLT goals, 24 (75\%) confronted with the challenge of time constraints for proper assessment and feedback and $22(69 \%)$ highlighted that the final assessment taken by Board of Intermediate and Secondary Education is incompatible with the communicative language teaching goals. It indicates that final assessment of the students is extremely affecting the CLT goals. On the other hand, time constraints are also posing challenges to the teachers to ensure proper assessment and feedback. Moreover, final assessment was also highlighted as incompatible with curriculum desired objectives.

The summary of all the major challenges is presented in the following diagram and colour of each bar represents the category of challenges. 


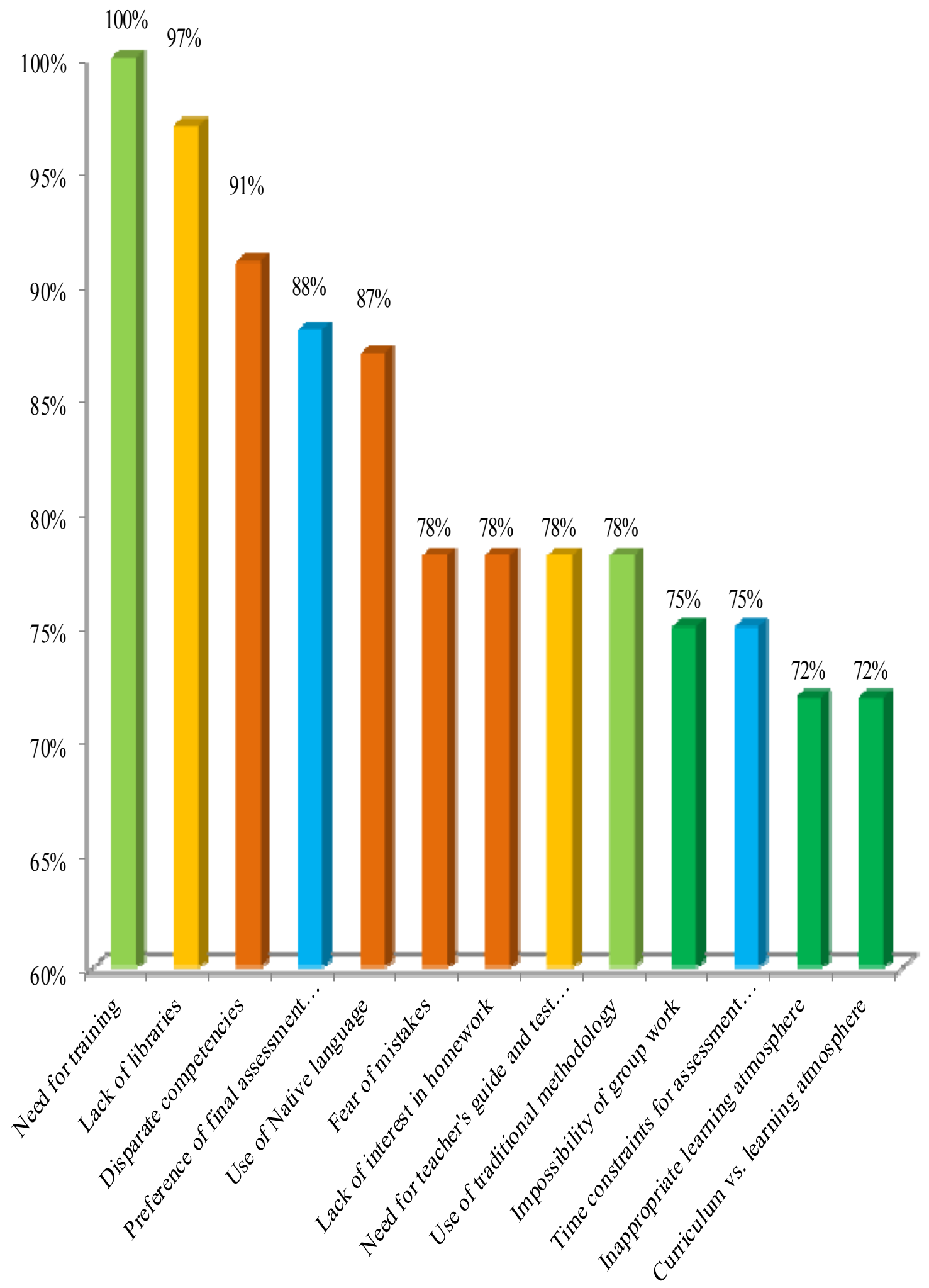

Figure 6.

It highlights that teachers needed training to deal with certain challenges especially disparate competences and schools needed appropriate libraries to help teachers to plan their lessons effectively. However, the importance of other challenges cannot be denied. 


\section{Results and Findings}

Newly inducted teachers faced diverse challenges in the implementation of the revised English curriculum. These challenges are briefly summarized in the subsequent paragraphs:

The current study revealed that all the teachers need training to effectively implement the revised English curriculum and it conforms to the findings of Shahzada et al. (2012) and Nawab (2013) who highlighted the non-availability of in-service courses for secondary level English teachers. The findings of the study indicate that most $(97 \%)$ of the teachers faced the challenge of non-availability of suitable libraries. These findings are in line with the findings of Behlol \& Anwar (2011) who indicated the lack of libraries in the institutions at SSC level. It has been noted in the current study that most (91\%) of the teachers faced the challenge of students with disparate competencies in their classroom as it is quite difficult to deliver an effective lesson for the class of different levels of students. These findings validate Soomro et al. (2016) who highlighted in his study that large multilevel classrooms are a hindrance in applying new techniques.

The current study highlighted that most ( $88 \%$ ) of the teachers considered achieving examination results more important and valued by the school than achieving communicative language teaching goals. The findings of the study agree with Warsi (2004) and Nawab (2012) who found flaws in the examination system. It has been revealed in the current study that most $(87 \%)$ of the teachers considered it impossible to ban the use of native language in ESL classroom as students insist on translating what is happening to their native language. The current study reflects the findings of Aziz et al. (2015) who highlighted that the interference of the native language hindered the teaching-learning process. Rasheed et al. (2017) also highlighted similar findings that due to the weak linguistic background in English language, students stressed on the translation of every lesson.

It has been observed in the current study that the majority (78\%) of the teachers faced the challenge of non-availability of teacher guides and test books for each class for the effective implementation of the revised English curriculum. Warsi (2004) also noted that teachers are not equipped with effective pedagogical tools. The findings of the current study revealed that the majority $(78 \%)$ of the teachers faced the challenge of fear of mistakes among the students that causes them to communicate in the native language. These findings of the study are in line with the findings of Bilal et al. (2013) who found that even after studying English for eleven years, students still faced a lack of confidence. These findings are further validated by Haider (2014) and Gopang et.al (2015) in their studies. It has been highlighted in the current study that the majority (78\%) of the teachers considered homework good for students and the more time they spend working with English, the better they get at it. But the students do not usually do it. These findings are in line with the findings of Paudel (2012) who highlighted that ESL learners do not do homework due to certain reasons. It has been noted in the current study that the majority $(78 \%)$ of the teachers preferred to teach in the traditional way as they were unable to teach English through communicative language teaching method due to insufficient training. Findings of the study conform to the findings of Karim (2006), Faizi (2010), Behlol, \& Anwar (2011), Bacha, \& Ilyas (2014) who highlighted the use of outdated methods for teaching English.

The results of the study show that the majority (75\%) of the teachers cannot conduct a lesson based on small groups in a traditional classroom organization where desks are organized in rows. The findings of the study are in line with Teevno (2011) who highlighted that classroom management posed a great challenge in teaching and learning of English. The worth following strategy is that the teacher should make a proper seating plan considering the competence of all the students and then make their groups. Another important finding was that the majority $(75 \%)$ of the teachers faced the challenge of assessing students performing a variety of activities and getting proper feedback due to time constraints. Insufficient time allocation has also been highlighted by Teevno (2011). In such cases, sample assessment can help the teacher overcome the challenges.

It was found in the current study that the majority (72\%) of the teachers faced the challenge of atmosphere inappropriate for communicative language teaching. The findings of the study are in line with the study conducted by Soomro et al. (2016) where they found that teaching strategies do not create a better learning environment. In the variable classroom dynamics, teachers can adopt the strategies depending upon the kind of inappropriateness they face like making their classroom attractive, systematic seating arrangement, improvement of lightening condition etc. It is very important to note that the majority (72\%) of the teachers considered that the revised English curriculum is not compatible with the existing learning atmosphere. The findings of the study further agree with Aziz et al. (2015) who noted that the curriculum was not according to the needs of students. Adapting the existing curriculum according to the needs of the learners and relating it with existing learning atmosphere is the strategy worth following. 


\section{Conclusions and Implications}

In the light of findings stated above, the current research entails following implications:

(i) Newly inducted teachers need to be trained according to the demands of curriculum defined methodology embedded with innovative tools to cope with the challenges highlighted above.

(ii) English language teaching curricula of professional courses like B.Ed need to be revised and synchronized with the needs of revised English curriculum. Teachers inducted in future will be better equipped to cope with diverse challenges.

(iii) The government and the school administration should put all its efforts to manage resources like libraries equipped with internet facilities and language labs well-furnished with audio visual aids required for English language learning.

(iv) There is a dire need to synchronize written curriculum, taught curriculum and examined curriculum. Keeping time constraints in teaching and assessment into consideration, all the stakeholders should prefer communicative language teaching goals to attain curriculum desired learning objectives and the final assessment should subordinate to the taught curriculum.

(v) Teachers and the head teachers should play their roles in the improvement of classroom environment for effective learning.

Although this study has investigated the challenges faced by newly inducted teachers implementing revised English curriculum at the secondary level in district Abbottabad, more research of this kind will be handy both in Khyber Pakhtunkhwa and elsewhere. Further study of the exploration of challenges and strategies pertaining to revised English curriculum at any other academic level like the primary or elementary level in district Abbottabad or any other district will be valuable to build on the insights highlighted in this study. The findings from this study can provide the basis for the design of a survey in which the challenges of a wider range of teachers can be studied. Additionally, further research with inspectors and Education Ministry officials to understand their challenges might be insightful.

Throughout this study, teachers frequently referred to the need for training to implement the revised English curriculum effectively. Further research can be conducted to assess the needs of newly inducted teachers implementing the revised English curriculum to plan better training. Moreover, the assessment of these needs can be useful to add some innovation in outdated professional courses like B.Ed. Finally, the entire study dealt with the challenges faced by teachers. Further research is needed to examine students' challenges in receiving revised English curriculum. For example, if the curriculum expects the students to make speaking English a regular activity, to participate in classroom activities, and to work in pairs, then it is important to understand what challenges students face during these activities.

\section{References}

Adalat, M. (2005). A study of problems faced by female English language teacher at primary level in district Rawalpindi. (Unpublished master's thesis). Allama Iqbal Open University Islamabad, Pakistan.

Afzaal, M., Khan, M., Ghaffar Bhatti, A., \& Shahzadi, A. (2019). Discourse and Corpus based Analysis of Doctor-Patient Conversation in the Context of Pakistani Hospitals. European Online Journal of Natural and Social Sciences, 8(4), 732.

Ahmad, N., Khan, F. N., \& Munir, N. (2013). Factors affecting the learning of English at secondary school level in Khyber Pakhtunkhwa, Pakistan. International Journal of English Language and Literature Studies, 2(2), 95-101.

Afzaal, M., Hu, K., Chishti, M. I., \& Imran, M. (2019). A Study of Pakistani English Newspaper Texts: An Application of Halliday and Hasan's Model of Cohesion: A Discourse Analysis. International Journal of English Linguistics, 9(5). https://doi.org/10.5539/ijel.v9n5p78

Bacha, M. S., \& Ilyas, M. (2014.) The Teaching of English Language in the Private Schools of Dir Upper, KPK, Pakistan. BEST: International Journal of Humanities, Arts, Medicine and Sciences (BEST: IJHAMS), 2(11), 43-54.

Bantwini, B. D. (2010). How teachers perceive the new curriculum reform: Lessons from a school district in the Eastern Cape Province, South Africa. International Journal of Educational Development, 30, 83-90. https://doi.org/10.1016/j.jijedudev.2009.06.002

Bashiruddin, A., \& Qayyum, R. (2014). Teachers of English in Pakistan: Profile and recommendations. NUML 
Journal of Critical Inquiry, 12(1), 1

Behlol, M. G., \& Anwar, M. (2011). Comparative Analyses of the Teaching Methods and Evaluation Practices in English Subject at Secondary School Certificate (SSC) and General Certificate of Education (GCE O-Level) in Pakistan. International Education Studies, 4(1), 202-211. https://doi.org/10.5539/ies.v4n1p202

Carless, D. R. (1998). A case study of curriculum implementation in Hong Kong. System, 26(3), 353-368. https://doi.org/10.1016/S0346-251X(98)00023-2

Crystal, D. (1997). English as a global language. Cambridge university press.

Fook, C. Y., \& Sidhu, G. K. (2010). Authentic assessment and pedagogical strategies in higher education. Journal of Social Sciences, 6(2), 153-161. https://doi.org/10.3844/jssp.2010.153.161

Faizi, W. U. (2010). The main reasons of declining educational standards at secondary level in Karachi, Pakistan. https://doi.org/10.2139/ssrn.1601268

Gömleksiz, M. N. (2005). An Evaluation of the Effectiveness of New Turkish Primary School Curriculum in Practice. Educational sciences: theory \& practice, 5(2).

Hassan, F., \& Selamat, N. F. (2002). Why aren't students proficient in ESL: The teachers' perspective. The English Teacher.

Karim, T. (2006). Test of English at SSC level in district Skardu: Causes of failure and their remedial measures. Islamabad. (Unpublished master's thesis). Allama Iqbal Open University, Pakistan.

Karavas-Doukas, E. (1995). Teacher identified factors affecting the implementation of an EFL innovation in Greek public secondary schools. Language, Culture and Curriculum, 8(1), 53-68. https://doi.org/10.1080/07908319509525188

Kausar, G., \& Akhtar, R. N. (2012). Teachers' perception regarding the effect of curriculum and examination system on Pakistani college students' English language performance. Journal of Education and Practice, $3(16), 219-222$.

Kırkgöz, Y. (2009). Globalization and English language policy at primary education in Turkey. English as an International Language Journal, 5, 176-181. https://doi.org/10.1177/0895904808316319

Likert, R. (1932). A Technique for the Measurement of Attitudes. Archives of Psychology, 140, 1-55.

Mugenda, O. M., \& Mugenda, G. A. (2003). Research methods Quantitative and Qualitative Approaches. Nairobi: ACTS.

Nawab, A. (2012). Is it the way to teach language the way we teach language? English language teaching in rural Pakistan. Academic Research International, 2(2), 696.

Orafi, S. M. S. (2008). Investigating teachers' practices and beliefs in relation to curriculum innovation in English language teaching in Libya. Unpublished doctoral dissertation, University of Leeds.

Orafi, S. M. S., \& Borg, S. (2009). Intentions and realities in implementing communicative curriculum reform. System, 37, 243-253. https://doi.org/10.1016/j.system.2008.11.004

O'Sullivan, M. C. (2002). Reform implementation and the realities within which teachers work: A Namibian case study. Compare: A Journal of Comparative and International Education, 32(2), 219-237. https://doi.org/10.1080/03057920220143192

Pandian, A. (2002). English language teaching in Malaysia today. Asia Pacific Journal of Education, 22(2), 35-52. https://doi.org/10.1080/0218879020220205

Shahzada, G., Ghazi, S. R., \& Khan, U. A. (2012). Causes of rising failure of the students' in the subject of English at Secondary Level. Mediterranean Journal of Social Sciences, 3(1), 605-611.

Sidhu, G. K., Chan, Y. F., \& Kaur, S. (2010). Instructional practices in teaching literature: Observations of ESL classrooms in Malaysia. English Language Teaching, 3(2), 54. https://doi.org/10.5539/elt.v3n2p54

Soomro, M. A., Memon, N., \& Memon, S. A. (2016). Concept of Best Practices in English Language Teaching to Pakistani ELT Fraternity. Advances in Language and Literary Studies, 7(4), 119-123. https://doi.org/10.7575/aiac.alls.v.7n.4p.119

Tabatabaei, O., \& Pourakbari, A. A. (2012). An Investigation into the Problems of Teaching and Learning English in the Isfahan Province High Schools, Iran. Journal of Language Teaching \& Research, 3(1). https://doi.org/10.4304/jltr.3.1.102-111 
Teevno, R. A. (2011). Challenges in teaching and learning of English at Secondary Level Class X. International Journal of Human Resource Studies, 1(2), 27. https://doi.org/10.5296/ijhrs.v1i2.1029

Tilfarlığlu, F. Y., \& Öztürk, A. R. (2007). An Analysis of ELT Teachers' Perceptions of Some Problems Concerning the Implementation of English Language Teaching Curricula in Elementary. Journal of Language and Linguistic Studies, 3(1).

Wang, H. (2008). Language policy implementation: A look at teachers' perceptions. Asian EFL Journal, 30(1), $1-38$.

Warsi, J. (2004). Conditions under which English is taught in Pakistan: An applied linguistic perspective. Sarid Journal, 1(1), 1-9.

\section{Copyrights}

Copyright for this article is retained by the author(s), with first publication rights granted to the journal.

This is an open-access article distributed under the terms and conditions of the Creative Commons Attribution license (http://creativecommons.org/licenses/by/4.0/). 